\title{
The Antibacterial, Insecticidal and Nematocidal Activities and Toxicity Studies of Tanacetum falconeri Hook. f.
}

\section{Tanacetum falconeri Hook. f'nin Antibakteriyel, İnsektisidal ve Nematosidal Aktiviteleri ve Toksisite Çalışmaları}

\author{
(D) Muhammad ISMAIL ${ }^{1 *}$, (D) Atia KOWSAR¹, (D) Salma JAVED², (D) M. Iqbal CHOUDHARY ${ }^{3}$, (D) Sher Wali KHAN4, (D) Qamar ABBAS ${ }^{4}$, \\ (D) Yanran TANG 5 , (D) Wei WANG 5 \\ ${ }^{1}$ Karakoram International University, Department of Chemistry, Gilgit, Pakistan \\ 2University of Karachi, National Nematological Research Centre, Karachi, Pakistan \\ 3University of Karachi, International Center for Chemical and Biological Sciences, Karachi, Pakistan \\ ${ }^{4}$ Karakoram International University, Department of Biological Sciences, Gilgit, Pakistan \\ 5 Hunan University of Chinese Medicine Faculty of Pharmacy, TCM and Ethnomedicine Innovation \& Development International Laboratory, Hunan, China
}

\begin{abstract}
Objectives: Secondary bioactive metabolites from plants may be realistic alternatives to conventional synthetic chemicals. The aim of the present research was to test the Tanacetum falconeri Hook. f. in different bioassays to evaluate its potential as nematocidal, insecticidal, antibacterial, cytotoxic, and phytotoxic agent. The plant T. falconeri was further studied for its chemical constituents.

Materials and Methods: The methanolic extract from T. falconeri was fractionated into various solvent fractions. All solvent fractions were further subjected to different bioassays. Antibacterial activity and cytotoxicity were determined by broth micro-dilution method and 3-(4,5-dimethylthiazol2-yl)-2,5-diphenyltetrazolium bromide assay, respectively. Nematocidal activity was evaluated by using second-stage juvenile of Meloidogyne incognita. Insecticidal activity and phytotoxicity were measured with the help of Rhyzopertha dominica and Tribolium castaneum and fronds of Lemna minor L., respectively. Compound-1 was isolated by using liquid chromatography and its structure was determined by spectroscopic data as cisdehydromatricaria ester.

Results: The excellent nematocidal activity (reduction in 100\% motility) of the compound-1 against a root-knot nematode was obtained at $1 \%$ concentration after $72 \mathrm{~h}$ incubation time, whereas the reductions in motilities were $95 \%$ and $75 \%$ at concentrations $0.5 \%$ (w/v) and $0.125 \%$ ( $\mathrm{w} / \mathrm{v}$ ), respectively. Similarly, the mortalities were $90 \%$ and $82 \%$ at $1 \%$ and $0.5 \%$ concentrations, respectively, after $24 \mathrm{~h}$ of the treatment. Compound- 1 also exhibited the excellent insecticidal activity against Sitophilus oryzae at $1 \%$ concentration (providing $100 \%$ mortality) with effective dose 50 (EC ${ }_{50}$ ) of $0.08 \mathrm{mg} / \mathrm{L}$. The $\mathrm{EC}_{50}$ of phosphine, which was used as standard, was $0.07 \mathrm{mg} / \mathrm{L}$. Two fractions of $T$. falconeri showed a moderate cytotoxic activity against 3 T 3 cells lines at the concentration of $30 \mathrm{mg} / \mathrm{mL}$ with inhibitory concentration 50 values of 22.4 and $25.8 \mathrm{mg} / \mathrm{L}$ corresponding to TfP and TfM, respectively.
\end{abstract}

Conclusion: This study demonstrates that cis-dehydromatricaria ester-1 provides nematocidal activity (100\% mortality) against the root-knot nematodes. Its insecticidal activity against $S$. oryzae may enable its use as marketable insecticide.

Key words: Pesticides, Tanacetum falconeri, secondary metabolites, root-knot nematodes, toxicity

ÖZ

Amaç: Bitkilerden elde edilen ikincil biyoaktif metabolitler, geleneksel sentetik kimyasallara gerçekçi alternatifler olabilir. Bu araştırmanın amacı farklı biyoyöntemlerle Tanacetum falconeri Hook. f.'nin nematosidal, insektisidal, antibakteriyel, sitotoksik ve fitotoksik ajan olarak potansiyelini test etmektir. T. falconeri bitkisi, kimyasal bileşenleri için daha ileri incelemelere de tabi tutulmuştur. 
Gereç ve Yöntemler: T. falconeri'den elde edilen metanolik ekstre çeşitli çözücü fraksiyonlarına bölünmüştür. Tüm çözücü fraksiyonları ayrıca farklı biyoyöntemlere tabi tutulmuștur. Antibakteriyel aktivite ve sitotoksisite, sırasıyla broth mikro seyreltme yöntemi ve 3-(4,5-dimetiltiazol2-il)-2,5-difeniltetrazolyum bromür yöntemi ile belirlenmiștir. Nematosit aktivitesi, Meloidogyne incognita'nın ikinci evre yavrusu kullanılarak değerlendirilmiștir. İnsektisidal aktivitesi ve fitotoksisitesi, sırasıyla Rhyzopertha dominica ve Tribolium castaneum ve Lemna minor L.'nin yaprakları yardımıyla ölçülmüştür. Bileșik-1, sıvı kromatografi kullanılarak izole edilmiş ve yapısı cis-dehidromatricaria ester olarak spektroskopik verilerle belirlenmiştir.

Bulgular: Bileşik-1'in bir kök-düğüm nematoduna karşı mükemmel nematosidal aktivitesi (\%100 motilitede azalma), 72 saatlik inkübasyon süresinden sonra \%1 konsantrasyonda elde edilirken, motilitelerdeki azalmalar \%0,5 ve \%0,125 (a/h) kosantrasyonlarda sırasılyla; ka \%95 ve \%75 olarak belirlenmiştir. Benzer şekilde, uygulamadan 24 saat sonra ölümler sırasıyla \%1 ve \%0,5 konsantrasyonlarda \%90 ve \%82 olarak belirlenmiştir. Bileșik-1 ayrıca, 0,08 mg/L'lik etkin doz $50\left(\mathrm{EC}_{50}\right)$ ile \%1 konsantrasyonda (\%100 ölüm sağlar). Sitophilus oryzae'ye karșı mükemmel insektisidal aktivite sergilemiştir. Standart olarak kullanılan fosfinin $\mathrm{EC}_{50}$ 'si $0,07 \mathrm{mg} / \mathrm{L}$ olarak belirlenmiștir. T. falconeri'nin iki fraksiyonu, sırasıyla TfP ve TfM'ye karşılık gelen 22,4 ve 25,8 mg/L'lik inhibitör konsantrasyon 50 değerleri ile 30 mg/mL konsantrasyonda $3 T 3$ hücre hatlarına karşı orta derecede sitotoksik aktivite göstermiştir.

Sonuç: Bu çalışma, cis-dehidromatricaria ester-1'in kök-düğüm nematodlarına karşı nematosidal aktivite (\%100 ölüm) sağladığını göstermektedir. S. oryzae'ye karşı insektisidal aktivitesi, pazarlanabilir insektisit olarak kullanılmasını sağlayabilir.

Anahtar kelimeler: Pestisitler, Tanacetum falconeri, sekonder metabolitler, kök-dügüm nematodları, toksisite

\section{INTRODUCTION}

Asteraceae family belongs to the flowering plants having 23,000 species of 12 sub-families and 1,620 genera.' The family is quite diverse group of vascular plants containing shrubs, trees, and vines widely grown in sub-tropical and lower temperature latitude regions. ${ }^{2}$ Worldwide, this family is used in medicines, cosmetics, and pesticidal products., ${ }^{2,3}$ The genus Tanacetum commonly known as tansy belongs to the family Asteraceae and contains 200 species across the globe and abundantly found in Europe and Western Asia. ${ }^{4,5}$ These species contain several biologically active compounds that are extensively used in herbal medication and in cosmetics. ${ }^{6}$ Tanacetum species have vast medicinal importance and used to cure different diseases for many centuries. Many species of Tanacetum are used as an edible vegetable as well as medicinal plants. Different classes of secondary metabolites, including flavonoids, phenolic acids, sesquiterpene lactone, monoterpene, diterpene, glycosides, alkaloid, phytosterol, heterocyclic compounds, and polyacetylenes, have been reported from the different species of Tanacetum. Biologically, plants of genus Tanacetum have shown a variety of activities including insect anti-feedant and antimicrobial properties. ${ }^{7}$ In addition to this, different species of genus Tanacetum also have biological activities like antimicrobial, cytotoxicity, growth regulating, phytotoxic, anti-ulcer, anthelmintic, anti-fungal, and antioxidant activities. ${ }^{2}$ Tanacetum chiliophyllum has shown a promising insecticidal activity against the stored granary products pest $S$. granaries. ${ }^{8}$ Similarly, compounds isolated from $T$. chiliophyllum have been reported in the literature to possess cytotoxic, antimicrobial activities, and acetylcholinesterase, butyrylcholinesterase inhibitory effects. ${ }^{9}$ Many sesquiterpene lactones and flavonoids as anti-inflammatory agents have been isolated from Tanacetum sinaicum. ${ }^{10}$ Pyrethroids are commercial insecticidal compounds isolated from Chrysanthemum cinerariaefolium."

In this paper, we report cis-dehydrometricaria ester (compound-1) for the first time from T. falconeri, which has been further tested for its nematocidal and insecticidal activities. In addition to this, different fractions of $T$. falconeri extract have been screened for their potential nematocidal, insecticidal, antibacterial, cytotoxic, and phytotoxic activities.

\section{MATERIALS AND METHODS}

\section{General experimental procedure}

Analytical and laboratory grade of different chemicals including reagents and solvents were purchased from the trustworthy chemical companies (e.g., E. Merck, Fisher Scientific). For soaking and extraction, commercial grade of different solvents (methanol, $n$-hexane, ethyl acetate, and dichloromethan) were utilized. While chromatography and purification of the isolated compound was carried out by using distilled solvents. Silica gel was used as adsorbents for liquid column chromatography (E. Merck: 100-380 $\mu \mathrm{m}$ mesh). For determining samples purity pre-coated silica gel plates (GF 254, TLC) were used. Bruker $\mathrm{AM}-400$ and $\mathrm{AMX}-500$ and $125 \mathrm{MHz}$ instrument was utilized for ${ }^{1} \mathrm{H}$-and ${ }^{13} \mathrm{C}$-NMR (1D and $2 \mathrm{D}$ spectra), respectively. By using the reference solvent proton signal of $\mathrm{CDCl}_{3}$, chemical shifts values were represented in ppm and coupling constant $(\mathrm{J})$ were represented in $\mathrm{Hz}$. To determine the exact mass of the pure compounds, at $70 \mathrm{eV}$ Electron-impact mass spectra was noted by using Finnigan MAT-112 instrument.

\section{Collection of plant material}

The collection of plant Tanacetum falconeri Hook. f. $(5.2 \mathrm{~kg})$ was carried out in July 2017 from Astore (Daosai). The identification of the plant was done in Karakoram International University Gilgit Baltistan, by the taxonomist Dr. Sher Wali Khan. The specimen (voucher no. 145/17) has been stored and protected at the herbarium of the department of biological sciences, KIU for future reference.

\section{Preparation of sample extracts}

The air-dried aerial parts of T. falconeri Hook. f. $(2.18 \mathrm{~kg})$ was extracted three times $(3 \times 2 \mathrm{~L})$ with $95 \%$ methanol at $20^{\circ} \mathrm{C}$ by soaking for three days each time. Following filtration, the combined methanol extracts were evaporated by using a rotary evaporator at $40^{\circ} \mathrm{C}$ to dryness, to obtain the $T$. falconeri whole 
plant extract (TfP) (105 g, TfP). The combined and concentrated TfP was further dissolved in water $(500 \mathrm{~mL})$ and extracted with $n$-hexane $(3 \times 500 \mathrm{~mL})$ first, and water was evaporated by using a rotary evaporator to get the concentrated $\mathrm{MeOH}$ extract [91 g, T. falconeri methanolic ( $\mathrm{TfM})$ ]. The methanolic extract was further fractionated through the successive solvent-solvent extractions with ethyl acetate $(3 \times 300 \mathrm{~mL})$, and $n$-butanol saturated with $\mathrm{H}_{2} \mathrm{O}(3 \times 250 \mathrm{~mL})$ in a separatory funnel. Each extract, as well as its remaining aqueous phase $\left(\mathrm{R}-\mathrm{H}_{2} \mathrm{O}\right)$ after solvent extractions were evaporated to dryness under a reduced pressure to yield an $n$-hexane fraction $[14 \mathrm{~g}, T$. falconeri hexane $(\mathrm{TfH})]$, EtOAc fraction [37 g, T. falconeri ethyl acetate (TfE)], $n$-BuOH fraction [13 g, T. falconeri butanolic (TfB)], and $\mathrm{R}-\mathrm{H}_{2} \mathrm{O}$ fraction $[25 \mathrm{~g}, T$. falconeri aqueous (TfA)], respectively.

\section{Isolation of compound-1}

The EtOAc extract (37 g) obtained from the methanolic extract of Tanacetum falconeri Hook. f. was subjected to silica gel column chromatography. At first, system was eluted with $100 \% n$-hexane, and then by using respective solvent system of $n$-hexane: EtOAc (98:2, 95:5, 93:7, 90:10, 88:12, 85:15, 80: $20,70: 30,50: 50)$; and finally washed with $100 \%$ ethyl acetate; and then with 50:50 ethyl acetate; and methanol (1L with each polarity). At the end 64 fractions (TF1-TF64) were obtained from the column. At gradient of $n$-hexane: Ethyl acetate (98:2) pure compound-1 was obtained.

Physical state: Colorless needle crystals. ESI-MS (+Ve) m/z: 173.0589[M+H] $]^{+}$. Molecular formula: $\mathrm{C}_{11} \mathrm{H}_{8} \mathrm{O}_{2}$. ${ }^{1} \mathrm{H}-\mathrm{NMR}:\left(\mathrm{CDCl}_{3}\right.$, $600 \mathrm{MHz}) \delta$ ppm: $6.25(1 \mathrm{H}, \mathrm{d}, \mathrm{J}=11.4 \mathrm{~Hz}, \mathrm{H}-2), 6.14(1 \mathrm{H}, \mathrm{d}, \mathrm{J}=11.4$ $\mathrm{Hz}, \mathrm{H}-3), 3.75\left(3 \mathrm{H}, \mathrm{s}, \mathrm{H}-1^{\prime}\right), 1.99$ (3H, s, H-10). ${ }^{13} \mathrm{C}-\mathrm{NMR}:\left(\mathrm{CDCl}_{3}\right.$, $150 \mathrm{MHz}$ ) $\delta$ ppm: 164.5 (C-1), 132.53 (C-2), 121.55 (C-3), 86.14, $80.82,72.19,70.97,64.82,58.39$ (C-4-C-9, acetylenic carbons), $51.7\left(\mathrm{C}-1^{\prime}\right), 4.80(\mathrm{C}-10)$.

\section{Biological assays}

All the extract fractions and pure compound-1 of Tanacetum falconeri were subjected to different biological assays including nematocidal, insecticidal, cytotoxic, antibacterial, and phytotoxic activities.

\section{Nematocidal activity}

The impact of six extracts and compound- 1 of $T$. falconeri were used to study the larval mortality of root-knot nematode. Inhabitants of second-stage juvenile (J2) of Meloidogyne incognita was obtained from culture on tomato plants in microplot of a screen room. From the infected tomato plant, the egg masses were collected and placed in a cavity block with water. The cavity block was placed under conditions that promote the development of egg hatching at an ambient temperature for 72 h. In the next stage, 100 larvae were counted in a chamber for each dose and replicated thrice to introduce in $3 \times 3$ glass cavity block. The stock solution was prepared by using $10 \mathrm{mg} / \mathrm{mL}$ plant extracts in $5 \%$ dimethyl sulfoxide (DMSO). Three concentrations of $1 \%, 0.5 \%$, and $0.125 \%$ were applied at a rate of $1 \mathrm{~mL}$ at each cavity block. Furadan was chosen as standard drug, while 5\% DMSO as a control treatment. Stereoscopic microscope was used to observe the percentage death rate (mortality) after an interval of 24,48 , and 72 h. Nematodes were considered dead when no movement was detected after a mechanical nudge. Then the nematode bodies were transferred into distilled water for conformation of irreversible mobility.

\section{Insecticidal activity}

By using the impregnated filter paper, Rhyzopertha dominica and Tribolium castaneum (insect species) were subjected to the methanolic extract and all solvent fractions.12-14 Stock solution was made by mixing the sample $(200 \mathrm{mg})$ in methanol (3 $\mathrm{mL}$ ). On Petri-plates with the help of micropipette samples $\left(1019.10 \mu \mathrm{g} / \mathrm{cm}^{2}\right)$, were applied to filter paper of size $9 \mathrm{~cm}$ or $90 \mathrm{~mm}$. The solvent evaporated after $24 \mathrm{~h}$. From each species, ten insects were set in each plate for test and control. For positive and negative control, $239.5 \mu \mathrm{g} / \mathrm{cm}^{2}$ of Permethrin and methanol were used, respectively. After maintaining the ambient temperature and $50 \%$ humidity in growth chamber, the test plates were incubated in the chamber for $24 \mathrm{~h}$. The next day, from each species the number of survivals was calculated, and percentage mortality $(\% M)$ was determined by applying the formula given below:

$$
\% M=\frac{100-\text { No. of insects alive in test }}{\text { No. of insects alive in control }} \times 100
$$

\section{Insecticidal activity of compound-1}

In laboratory conditions, compound was diluted in 5\% DMSO to acquire the different concentrations ( $1 \%, 0.5 \%$, and $0.125 \%)$. Ten active adults of rice weevil were collected from rearing cage and commence in Petri dishes ( $90 \mathrm{~mm}$ diameter) bottomed with filter paper disk (whatman no. 1), applied $1 \mathrm{~mL}$ each compound and concentration separately. The Petri dishes were sealed by parafilm (PM-996) and kept at $28 \pm 2^{\circ} \mathrm{C}$. Pesticide phosphine was chosen as a standard drug. Mortality was recorded after 24, 48 , and $72 \mathrm{~h}$ of intervals with $5 \%$ DMSO as a control treatment. Each treatment was replicated three times.

\section{Statistical analysis}

To analyze the treatment differences multifactor analysis of variance was used. By using SPSS statistical software, the obtained data was further submitted to Duncans' multiple range test $(p \leq 0.05)$. Probit analysis was done under survival analysis for effective dose $50\left(E_{50}\right)$ values by SAS, 2000 software.

\section{Antibacterial activity}

With the help of broth microdilution method, minimum inhibition concentration was recoded. The required tests were carried out by application of Tween-80, and a final concentration of $0.5 \%$ $(\mathrm{v} / \mathrm{v})$ in Mueller Hinton Broth. For preparation of serial doubling dilutions of the extract 96-well microtiter plate (200-25 ppm) were used. A concentration of $10 \mu \mathrm{L}$ of indicator solution and $10 \mu \mathrm{L}$ of Mueller Hinton Broth were mixed. Then, $10 \mu \mathrm{L}$ of bacterial suspension (106 CFU/mL) was mixed to each well to attain a concentration of $104 \mathrm{CFU} / \mathrm{mL}$. Each plate was covered with cling film to avoid water loss. The plates were prepared in triplicates to calculate the average of three values. The sample plates were then set in an incubator for $24 \mathrm{~h}$ at $37^{\circ} \mathrm{C}$. The lowest concentration was obtained by observing the color change with 
naked eye. The growth of microorganism was indicated by turbidity. 15,16

\section{Cytotoxicity (3-(4,5-dimethylthiazole-2-yl)-2,5-diphenyl- tetrazolium bromide) (MTT)}

The cytotoxicity of different extracts of $T$. falconeri was studied by applying the standard MTT colorimetric assay on 96-well micro plates. ${ }^{17}$ In this process, mouse fibroblast cells (3T3) were cultured in Dulbecco's modified eagle medium and mixed with $5 \%$ of fetal bovine serum, $100 \mathrm{IJ} / \mathrm{mL}$ of penicillin and 100 $\mu \mathrm{g} / \mathrm{mL}$ of streptomycin in $75-\mathrm{cm}^{2}$ flasks. The flasks were placed in incubator at $37^{\circ} \mathrm{C}$ having $5 \% \mathrm{CO}_{2}$. Hemocytometer was used to calculate the growing cells, and the dilution of cells with medium was also done. Cell suspension $\left(5 \times 10^{4}\right.$ cells $\left./ \mathrm{mL}\right)$ was prepared and added (100 $\mu \mathrm{L} /$ well) into 96 -well plates. After 12 $\mathrm{h}$ of incubation, the medium was removed and $200 \mu \mathrm{L}$ of fresh medium containing different concentrations of samples (1-30 $\mathrm{mg} / \mathrm{L}$ ) was added. After $48 \mathrm{~h}$, the medium was removed and $200 \mu \mathrm{L} \mathrm{MTT}(0.5 \mathrm{mg} / \mathrm{mL})$ was added to each well after $48 \mathrm{~h}$ and was kept for further $4 \mathrm{~h}$ incubation. Later, $100 \mu \mathrm{L}$ of DMSO was mixed to each well. The amount of MTT decrease to formazan within cells was obtained with the help of a micro plate reader by determining the absorbance at $540 \mathrm{~nm}$. The cytotoxic activity was noted as inhibitory concentration $50\left(\mathrm{IC}_{50}\right)$ for $3 \mathrm{~T} 3$ cell. At last, \% inhibition of cells was determined by applying the formula which is given below:

$\%$ inhibition $=\frac{100-(\text { mean of O. D of test compound }- \text { mean of O. D of }- \text { ve control })}{(\text { mean of O.D of }+ \text { ve control }- \text { mean of O.D of }- \text { ve control })} \times 100$

\section{Phytotoxicity}

The crude methanolic and remaining solvent fractions of $T$. falconeriwere subjected to the phytotoxicity assay. ${ }^{18,19}$ For this purpose, a medium was prepared at a $\mathrm{pH}$ of 6.0-7.0 by adding distilled water $(1000 \mathrm{~mL})$ to $\mathrm{KOH}$ pellets. The extract $(30 \mathrm{mg})$ was mixed with methanol $(1.5 \mathrm{~mL})$ to a prepared stock solution. Three types of concentrations $(10,100$, and $1000 \mu \mathrm{g} / \mathrm{mL}$ ) were obtained after a dilution of stock solution of the extract. A total of nine flasks were obtained, among which three were prepared for each dilution. Under sterilized conditions, the solvent was kept overnight to evaporate the solvent. In next stage, to each flask, $20 \mathrm{~mL}$ medium and 10 plants were added, each one containing a rosette of two fronds of Lemna minor $L$. A flask with a medium used as a positive control and Paraquate (reference plant growth inhibitor) as a negative control. The sample flasks were placed in the growth cabinet of the incubator for one week at $30^{\circ} \mathrm{C}$. After incubation, the number of fronds in each sample flask was measured, and by using the following formula, growth regulation as a percent regulation was calculated.

$$
\% \text { regulation }=\frac{100-\text { No. of fronds in test }}{\text { No. of fronds in }- \text { ve control }} \times 100
$$

\section{RESULTS}

From the EtOAc fraction of $T$. falconeri, cis-dehydromatricaria ester-1 has been obtained (Figure 1). Column chromatography was used for the purification of the compound, and the structure was identified with the help of modern spectroscopic techniques. The structure of compound obtained from $T$. falconeri (EtOAc fraction) was confirmed as cis-dehydromatricaria ester by the analysis of spectral data of NMR (1D and 2D), whereas the molecular mass was obtained by using El-MS. The compound's data ( ${ }^{1} \mathrm{H}-\mathrm{NMR}$ and $\left.{ }^{13} \mathrm{C}-\mathrm{NMR}\right)$ were compared and matched with the reported data in the literature. ${ }^{20}$

In the current study, we evaluated the crude methanolic extract (95\%) and different fractions of $T$. falconeri for bioassays like nematocidal, cytotoxic, insecticidal, and phytotoxic activities, whereas the methanolic extract and all the solvent fractions of T. falconeri were also analyzed for their nematocidal activities.

\section{Nematocidal activity}

The nematocidal activity of $T$. falconeri extracts on larval mortality of Meloidogyne incognita (root-knot nematode) was studied at various concentrations after 24, 48, 72 hours incubation. The nematocidal activities of TfA, TfB, TfE, TfH, $\mathrm{TfM}$, and TfP of $T$. falconeri were more consistent at the concentration of $1 \%, 0.5 \%$, and $0.125 \%$ with the total larval mortality rate of $50-68 \%$ after $72 \mathrm{~h}$ incubation time. The results presented in Table 1 indicate that all the fractions of $T$. falconeri showed moderate activities of $60 \%$. The active fractions of $T$. falconeri were comparable to each other showing the activity against root-knot nematodes. We recommend in vivo testing of active extracts, which have been never reported yet to promote the green practices for sustainable agriculture and protection of the environment.

In addition to this, compound-1 was also tested for its nematocidal activity against root-knot nematode (M. incognita). Compound-1 showed excellent and exceptional activity of 100\%, $95 \%$, and $75 \%$ mortality at $1 \%, 0.5 \%$, and $0.125 \%$ after $72 \mathrm{~h}$ of the treatment, respectively. Whereas the activity at $1 \%, 0.5 \%$, and $0.125 \%$ after $48 \mathrm{~h}$ of treatment was recorded as $90 \%, 82 \%$, and $37 \%$ mortality of root-knot nematodes (Table 1 ).

\section{Insecticidal activity}

The insecticidal effect of $T$. falconeri TfP and all the solvent fractions were studied against $R$. dominica and $S$. oryzae. The insecticidal activity of all six fractions of the extract of $T$. falconeri was carried out using $1019.10 \mu \mathrm{g} / \mathrm{cm}^{2}$ with a reference to the standard drug permethrin $\left(239.5 \mu \mathrm{g} / \mathrm{cm}^{2}\right)$. The results revealed that activity of all fractions remain insignificant at all concentration. Therefore, the data results have not been

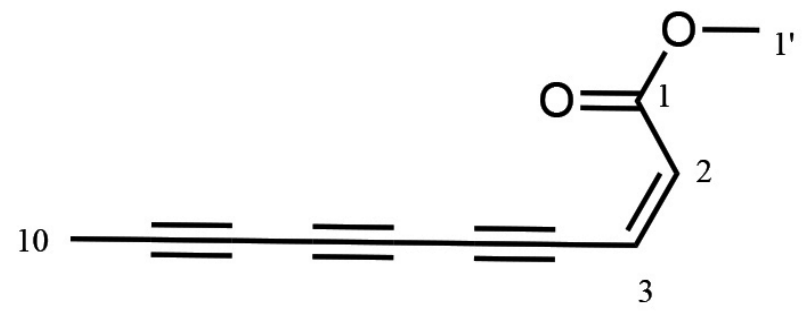

Figure 1. Structure of cis-dehydrometicaria ester (1) isolated from $T$. falconeri 
presented in the tabular form. The cis-dehydrometracaria ester (1) isolated from $T$. falconeri showed the strong insecticidal activity against stored grain pest (S. oryzae). In general, the mortality rate was increased with an increase in the concentration of compounds and exposure time. Compound-1 showed $100 \%$ mortality at $1 \%$ concentration comparable to a standard pesticide (phosphine). The $\mathrm{EC}_{50}$ values of compound-1 against S. oryzae were $0.0897 \mathrm{mg} / \mathrm{L}$ at $1 \%$ concentration after $72 \mathrm{~h}$ of incubation (Table 2 ).

\section{Cytotoxicity}

The cytotoxicity of $T$. falconeri (extract and all fractions) was examined at concentrations of $30 \mathrm{mg} / \mathrm{mL}$ with a reference to the standard drug cyclohexamide. The extracts of $T$. falconeri (methanol and whole plant) showed low inhibition with $I_{50}$ values of 22.4 and $25.8 \mathrm{mg} / \mathrm{L}$ against the $3 T 3$ normal cell lines, respectively (Table 3 ). The rest of the extracts including $n$-hexane, ethyl acetate, $n$-butanol and aqueous fractions were found inactive in MTT assay with inhibition $<20 \%$. Therefore, the insignificant data results have been not presented in the tabular form.

\section{Antibacterial activity}

The antibacterial susceptibility of all six extracts TfA, TfB, TfE, $\mathrm{TfH}, \mathrm{TfM}$, and TfP of $T$. falconeri were tested against $E$. coli, $B$. subtilis, Staphylococcus aureus, P. aeruginosa, and Salamonella typhi. The bacterial isolates were revived on nutrient agar. The bacterial cultures were preserved at $28^{\circ} \mathrm{C}$ prior to use, and periodic sub-culturing was done to maintain these cultures. The antibacterial activity of all the extract of $T$. falconeri with a standard drug ofloxacine presented in Table 4. All extracts have low inhibitory activity against tested bacterial strains, whereas,

Table 1. Nematocidal activity of different fractions from $T$. falconeri against root-knot nematode

\begin{tabular}{|c|c|c|c|c|c|}
\hline \multirow{2}{*}{ Sample } & \multirow{2}{*}{ Time (h) } & \multicolumn{3}{|c|}{ Concentration in $\%(w / v)$} & \multirow{2}{*}{${ }^{*} \mathrm{EC}_{50}( \pm \mathrm{SE}$} \\
\hline & & $0.125^{\star}$ & $0.5^{*}$ & $1 *$ & \\
\hline \multirow{3}{*}{ Compound-1 } & 24 & $22 \pm 2.0 c$ & $35 \pm 2.5 b$ & $42 \pm 1.3 a$ & $3.4 \pm 06$ \\
\hline & 48 & $37 \pm 1.2 c$ & $82 \pm 1.0 b$ & $90 \pm 1.5 a$ & $0.18 \pm 0.04$ \\
\hline & 72 & $75 \pm 1.0 c$ & $95 \pm 1.4 b$ & $100 \pm 0.0 a$ & $0.04 \pm 0.1$ \\
\hline \multirow{3}{*}{ TfA } & 24 & $10 \pm 1.0 c$ & $15 \pm 1.0 b$ & $25 \pm 0.5 a$ & $2.1 \pm 0.1$ \\
\hline & 48 & $45 \pm 1.5 b$ & $45 \pm 1.5 b$ & $50 \pm 2.0 a$ & $1.09 \pm 0.5$ \\
\hline & 72 & $55 \pm 1.1 \mathrm{Cb}$ & $60 \pm 1.5 \mathrm{Ba}$ & $60 \pm 0.5 a$ & $0.01 \pm 0.5$ \\
\hline \multirow{3}{*}{ TfB } & 24 & $10 \pm 2.0 c$ & $10 \pm 1.0 b$ & $15 \pm 1.0 a$ & $4.5 \pm 0.2$ \\
\hline & 48 & $35 \pm 1.0 a$ & $35 \pm 1.1 a$ & $35 \pm 1.5 a$ & $4.5 \pm 0.2$ \\
\hline & 72 & $60 \pm 1.0 b$ & $60 \pm 1.1 b$ & $65 \pm 1.0 a$ & $4.5 \pm 0.2$ \\
\hline \multirow{3}{*}{ TfE } & 24 & $15 \pm 1.5 b$ & $15 \pm 1.0 b$ & $25 \pm 1.1 a$ & $2.6 \pm 1.8$ \\
\hline & 48 & $40 \pm 1.0 b$ & $40 \pm 1.5 b$ & $45 \pm 2.0 a$ & $1.92 \pm 0.5$ \\
\hline & 72 & $62 \pm 1.0 b$ & $62 \pm 1.0 b$ & $68 \pm 1.5 a$ & $0.001 \pm 1.0$ \\
\hline \multirow{3}{*}{$\mathrm{TfH}$} & 24 & $15 \pm 0.5 b c$ & $18 \pm 1.0 b$ & $20 \pm 1.0 a$ & $4.8 \pm 0.3$ \\
\hline & 48 & $30 \pm 1.0 c$ & $30 \pm 2.0 b$ & $35 \pm 1.5 a$ & $3.4 \pm 0.4$ \\
\hline & 72 & $60 \pm 1.0 b c$ & $62 \pm 0.2 b$ & $65 \pm 1.5 a$ & $2.9 \pm 0.8$ \\
\hline \multirow{3}{*}{ TfM } & 24 & $12 \pm 1.0 c$ & $15 \pm 2.0 b$ & $18 \pm 1.0 a$ & $4.1 \pm 0.2$ \\
\hline & 48 & $32 \pm 1.0 b$ & $32 \pm 1.5 b$ & $35 \pm 1.0 a$ & $5.0 \pm 0.8$ \\
\hline & 72 & $60 \pm 1.0 c$ & $65 \pm 1.1 b$ & $68 \pm 0.5 a$ & $0.01 \pm 0.1$ \\
\hline \multirow{3}{*}{ TfP } & 24 & $10 \pm 0.5 b$ & $10 \pm 0.5 b$ & $15 \pm 0.2 \mathrm{a}$ & $4.5 \pm 0.2$ \\
\hline & 48 & $30 \pm 2.0 b$ & $30 \pm 2.0 b$ & $32 \pm 1.0 a$ & $4.5 \pm 0.6$ \\
\hline & 72 & $50 \pm 0.5 a$ & $50 \pm 2.0 a$ & $50 \pm 1.0 a$ & $4.5 \pm 0.6$ \\
\hline \multirow{3}{*}{ Carbofuran (furadan) } & 24 & $40 \pm 1.5 b$ & $100 \pm 0.0 a$ & $100 \pm 0.0 a$ & $0.13 \pm 0.02$ \\
\hline & 48 & $80 \pm 2.5 b$ & $100 \pm 0.0 a$ & $100 \pm 0.0 a$ & $0.07 \pm 0.3$ \\
\hline & 72 & $100 \pm 0.0 a$ & $100 \pm 0.0 a$ & $100 \pm 0.0 a$ & $0.07 \pm 0.3$ \\
\hline
\end{tabular}

*Values are in $\mathrm{mg} / \mathrm{L}$ : The concentrations of $1 \%, 0.5 \%$, and $0.125 \%$ were prepared by dissolving extract in $5 \% \mathrm{DMSO}(\mathrm{w} / \mathrm{v})$. Means followed by the same letter are not significantly different according to Tukey's test ( $p \leq 0.05$ ). TfA: T. falconeri aqueous, TfB: T. falconeri butanolic, TfE: T. falconeri ethyl acetate, TfH: T. falconeri hexane, TfM: T. falconeri methanolic, TfP: T. falconeri whole plant extract, EC 50 : Effective dose 50, SE: Standard error, DMSO: Dimethyl sulfoxide 
TfP was found inactive against $B$. subtilis, $P$. aeruginosa, and Salmonella typhi.

\section{Phytotoxicity}

The phytotoxic and insecticidal constituents are vital for the development of green herbicides and insecticides that are more eco-friendly than synthetic ones. The phytotoxic effect of the studied samples on L. minor was analyzed to have dosedependent activity because low activity was noticed in TfP, TfM, TfE, TfB, and TfA fractions, with $12.5 \%, 0 \%, 20 \%, 26.56 \%$, and $0 \%$ inhibition at $100 \mu \mathrm{g} / \mathrm{mL}$, respectively, and $0 \%$ inhibition at $10 \mu \mathrm{g} / \mathrm{mL}$ for all, in comparison to the Paraquat $(0.015 \mu \mathrm{g} /$ $\mathrm{mL}$ ) as a standard drug and control. Among the six fractions, $n$-hexane fraction had moderate and good phytotoxic activity (31.25\%, 77.08\% inhibition) at concentration at 10 and $100 \mu \mathrm{g} /$ $\mathrm{mL}$, respectively. A very significant phytotoxic effect $(100.0 \%$ inhibition) was observed at concentration of $1000 \mu \mathrm{g} / \mathrm{mL}$ for all fractions except TfB (68.75\%) and TfA (25\%) fractions of $T$. falconeri.

\section{DISCUSSION}

Meloidogyne incognita belongs to the family of nematodes and commonly called as root-knot nematode. The root-knot nematode found worldwide damages the roots of plants and ultimately decreases both quality and quantity of the plant. The affected plants show relatively slow growth rate and poor performance. To control the population of nematodes usually synthetic nematocides are used but these conventional nematocides are more vulnerable to the non-targeted organisms and ecologies. Hence more risk for environmental pollution problems arises. In these circumstances the green nematicodes (botanical nematicodes) are the best substituent of conventional chemicals to control the nematodes. The present study discussed certain botanical nematocides against $M$. incognita. In the present study, antibacterial, nematocidal, insecticidal, cytotoxic, and phytotoxic activities of $T$. falconeri were evaluated with the help of standard assay protocols. Extraction method is a key factor in obtaining the maximum quantity of active formulations from

\section{Table 2. Insecticidal activity compound-1 isolated from $T$. falconeri against rice weevils}

\begin{tabular}{|c|c|c|c|c|c|}
\hline \multirow{2}{*}{ Sample } & \multirow{2}{*}{ Time (h) } & \multicolumn{3}{|c|}{ Concentration in $\%(w / v)$} & \multirow{2}{*}{${ }^{*} \mathrm{EC}_{50}( \pm \mathrm{SE})$} \\
\hline & & $0.125^{*}$ & $0.5^{*}$ & $1^{*}$ & \\
\hline \multirow{3}{*}{ Compound-1 } & 24 & $30 \pm 1.5 c$ & $52 \pm 1.0 b$ & $62 \pm 1.0 a$ & $0.44 \pm 0.17$ \\
\hline & 48 & $45 \pm 1.0 c$ & $70 \pm 1.2 b$ & $80 \pm 2.5 a$ & $0.163 \pm 0.08$ \\
\hline & 72 & $62 \pm 1.5 c$ & $88 \pm 1.2 b$ & $100 \pm 0.0 a$ & $0.08 \pm 0.03$ \\
\hline \multirow{3}{*}{ Phosphine } & 24 & $80 \pm 0.5 c$ & $90 \pm 1.0 b$ & $100 \pm 0.0 a$ & $0.05 \pm 0.3$ \\
\hline & 48 & $90 \pm 2.0 b$ & $100 \pm 0.0 a$ & $100 \pm 0.0 a$ & $0.07 \pm 0.3$ \\
\hline & 72 & $100 \pm 0.0 a$ & $100 \pm 0.0 a$ & $100 \pm 0.0 a$ & $0.07 \pm 0.3$ \\
\hline
\end{tabular}

*Values are in $\mathrm{mg} / \mathrm{L}$ : The concentrations of $1 \%, 0.5 \%$, and $0.125 \%$ were prepared by dissolving extract in $5 \%$ DMSO ( $/ \mathrm{v}$ ). Means followed by the same letter are not significantly different according to Tukey's test ( $p \leq 0.05)$. EC $_{50}$ : Effective dose 50, SE: Standard error, DMSO: Dimethyl sulfoxide

Table 3. Cytotoxic activity of two fractions of $T$. falconeri against 3 T3 cell lines

\begin{tabular}{llll} 
Extract & Concentration $(\mathrm{mg} / \mathrm{mL})$ & $\%$ Inhibition & ${ }^{*} \mathrm{C}_{50} \pm \mathrm{SD}$ \\
\hline TfP & 30 & 55 & $22.4 \pm 2.8$ \\
\hline TfM & 30 & 67 & $25.8 \pm 2.5$ \\
\hline Std: Cyclohexamide & 30 & 70 & $8 \pm 0.2$ \\
\hline
\end{tabular}

*Values are in mg/L. TfM: T. falconeri methanolic, TfP: T. falconeri whole plant extract, IC 50 $_{50}$ Inhibitory concentration 50, SD: Standard deviation, Std: Standard

Table 4. Antibacterial susceptibility of $T$. falconeri against standard bacteria

\begin{tabular}{llllllll}
\multirow{2}{*}{ Bacteria } & \multicolumn{4}{l}{$\%$ Inhibition of different extracts (conc. $\mathbf{3 0 0 0} \mu \mathrm{g} / \mathrm{mL}$ ) } & & \% Inhibition of drug \\
\cline { 2 - 8 } & TfP & TfM & TfH & TfE & TfB & TfA & Ofloxacine \\
\hline E. coli & 11.32 & 18.01 & 10.84 & 22.55 & 27.37 & 6.80 & 95.52 \\
\hline B. subtilis & 0.00 & 1.23 & 16.37 & 17.65 & 22.42 & 29.57 & 95.19 \\
\hline Staphylococus aureus & 2.04 & 33.64 & 19.17 & 6.74 & 0.19 & 4.82 & 90.93 \\
\hline P. aeruginosa & 0.00 & 2.08 & 5.95 & 15.29 & 5.05 & 2.35 & 90.99 \\
\hline Salamonella typhi & 0.00 & 0.24 & 14.67 & 20.23 & 1.69 & 1.73 & 92.15 \\
\hline
\end{tabular}

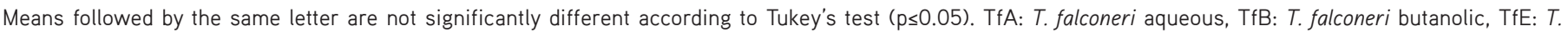
falconeri ethyl acetate, TfH: T. falconeri hexane, TfM: T. falconeri methanolic, TfP: T. falconeri whole plant extract 
target plant species. Methanol was used initially to ensure the maximum extraction of secondary metabolites from $T$. falconeri whereas, four different solvents with the variable degrees of polarity along with water were used in this study to divide the main extract into separate fractions, based on ingredients polarity. The methanolic and ethyl acetate fractions were more efficient than solvents with both lower polarity (hexane) and higher polarity (water). These results suggest that nematocidal compounds probably possess an intermediate degree of polarity or that $T$. falconeri contains several nematocidal compounds with different degrees of polarity.

Although the sensitivity of plant parasitic nematodes to nematocides varies among different extractives in general, in present study, the results are closely related to each other except the results for the methanolic extract. The results strongly support the profound ethnobotanical application of Tanacetum species and cis-dehydrometracaria ester (1). These results also demonstrate its potential for use in botanical pest control strategies. ${ }^{20}$ Control treatment fails to kill nematode while standard control carbofuran gave $100 \%$ mortality after $72 \mathrm{~h}$ of incubation with $\mathrm{EC}_{50}$ value $0.07 \pm 0.3 \mathrm{mg} / \mathrm{L}$, but it is toxic and extremely lethal to the mammals and the wildlife. Whereas in human beings, it causes reproductive disorders, genotoxic abnormalities, and endocrine disrupting activity. ${ }^{21}$ Carbofuran (Furadan') is used to control broad spectrum of insect is highly soluble white crystalline solid chemical and possess low adsorption properties in soil. ${ }^{22}$ The results of extractives and compound-1 showed an excellent activity and may be used as safe alternatives to replace the hazardous chemical products in the market. We recommend in vivo testing of active extracts, which have never been reported yet to promote the green practices for sustainable agriculture and the protection of the environment. In line with nematocidal activities, the insecticidal activity of the compound- 1 was found to be exceptional, which is consistent with the literature data. It has been reported that cis-dehydrometracaria ester isolated from Artemisia ordosica was tested against Tribolium castaneum at different concentrations (62.91, 12.58, 2.52, and $0.5 \mathrm{~nL} / \mathrm{cm}^{2}$ ). The pest repellent value has been reported higher than $90 \%$ at both 2 and $4 \mathrm{~h}$ incubation time. ${ }^{20}$ Phosphine pesticide has led to the selection of strong resistance against the major stored grain pest, including Sitophilus oryzae, Cryptolestes ferrugineus, Rhyzopertha dominica, Tribolium castaneum, and Liposcelis bostrychophila. It causes lethargy in humans which has been referred to as narcosis or anesthesia in animals. ${ }^{23}$ The promotion and development of green practices is in utmost need for the sustainable agriculture and the protection of the environment. The methanolic extract and different fractions of $T$. falconeri were found inactive against cytotoxicity, antibacterial, and phytotoxicity assays. This indicates the safe and effective nature of formulations from $T$. falconeri to the plants and animals for its sustainable application in agriculture, as well as health and well-being.

In summary, the results of the present study indicate that medium polar extracts in general and compound- 1 of $T$. falconeri potentially be developed into a commercial nematocide.
Although plant-based materials and extractives can be used in sustainable and organic farming, but isolation and identification of the nematocidal compounds is essential for further development of commercial products. Similarly, synthesis of active compounds or their derivatives with a higher nematocidal activity are likely to be a more promising means of developing a nematocide based on $T$. falconeri or related plant species.

\section{Study limitations}

Compound-1 could not have been tested for antibacterial, cytotoxic, and phytotoxic activities due to the limited quantity in hand. The nematocidal activity have been carried out on Meloidogyne incognita only whereas insecticidal activity against Rhyzopertha dominica and Tribolium castaneum. The results of $T$. falconeri extracts and compound- 1 are limited to the microorganisms stated in this study.

\section{CONCLUSION}

The investigation on green pesticides from plant origin is essentially vital for the progress of new botanical pesticides, especially in view of the vast worldwide flora. In summary, the current study revealed the ability of the different fractions of $T$. falconeri for their potential as cytotoxic, antibacterial, phytotoxic, nematocidal, and insecticidal agent. The results indicated that in development of plant-based green pesticides these plant species are a new potential source. These plants species may provide best alternative paths for controlling the different pests than synthetic pesticides with no worse impacts on ecology. Hence, detailed studies are required to find and investigate the functioning compounds, and their path of mechanism of action of these plant formulations, to introduce more safe products to the market, and substitute some of the present toxic chemicals already available and in practice. Opportunities exist to reduce chemical inputs to the environment provided by exploring the potential of pesticides based on plant products.

\section{ACKNOWLEDGMENTS}

The principal author (MI) acknowledges the financial support from the Higher Education Commission of Pakistan (project no. NRPU-3590) and PhosAgro/UNESCO/IUPAC (contract no. 4500319945).

Conflict of interest: No conflict of interest was declared by the authors. The authors are solely responsible for the content and writing of this paper.

\section{REFERENCES}

1. Pareek A, Suthar M, Rathore G, Bansal V. Feverfew (Tanacetum parthenium L.): A systematic review. Pharmacogn Rev. 2011;5:103-110.

2. Kumar V, Tyagi D. Chemical composition and biological activities of essential oils of Genus Tanacetum - a review. J Pharmacogn Phytochem. 2013;2:155-159.

3. Gao T, Yao H, Song J, Zhu Y, Liu C, Chen S. Evaluating the feasibility of using candidate DNA barcodes in discriminating species of the large Asteraceae family. BMC Evol Biol. 2010;10:324. 
4. Ismail M, Hussain F, Ali S. Botanical pesticide and insects repellent prepared from Tanacetum baltistanicum endemic to Gilgit-Baltistan. J Biodivers Environ Sci. 2014;5:128-135.

5. Orhan IE, Tosun F, Gülpinar AR, Kartal M, Duran A, Mihoglugil F, Akalgan D. LC-MS quantification of parthenolide and cholinesterase inhibitory potential of selected Tanacetum L. (Emend. Briq.) taxa. Phytochem Lett. 2015;11:347-352.

6. Salamci E, Kordali S, Kotan R, Cakir A, Kaya Y. Chemical compositions, antimicrobial and herbicidal effects of essential oils isolated from Turkish Tanacetum aucheranum and Tanacetum chiliophyllum var. chiliophyllum. Biochem Syst Ecol. 2007;35:569-581.

7. Bukhari IA, Khan RA, Gilani AUH, Shah AJ, Hussaun J, Ahmad VU. The analgesic, anti-inflammatory and calcium antagonist potential of Tanacetum artemisioides. Arch Pharm Res. 2007;30:303-312.

8. Polatoğlu K, Karakoç ÖC, Gökçe A, Goren N. Insecticidal activity of Tanacetum chiliophyllum (Fisch. \& Mey.) var. monocephalum grierson extracts and a new sesquiterpene lactone. Phytochem Lett. 2011;4:432435.

9. Polatoğlu K, Yücel YY, Nalbantsoy A, Yalcin HT, Goren N. Cytotoxic, antimicrobial activities, $\mathrm{AChE}$ and $\mathrm{BChE}$ inhibitory effects of compounds from Tanacetum chiliophyllum (Fisch. \& Mey.) Schultz Bip. var. oligocephalum (D.C.) Sosn. and T. chiliophyllum (Fisch. \& Mey.) Schultz Bip. var. monocephalum Grierson. Phytochem Lett. 2017;22:199-204.

10. Hegazy MEF, Hamed AR, Mohamed TA, Debbab A, Nakamura S, Mutsuda $\mathrm{H}$, Pare PW. Anti-inflammatory sesquiterpenes from the medicinal herb Tanacetum sinaicum. RSC Adv. 2015;5:44895-44901.

11. Kumar A, Singh SP, Bhakuni RS. Secondary metabolites of Chrysanthemum genus and their biological activities. Curr Sci. 2005;89:1489-1501.

12. Atta-ur-Rahman, Choudhary MI, Thomson WJ. Bioassay techniques for drug development. The Netherlands: Harwood Academic Publishers; 2001; p. 8-100.

13. Hagstrum DW, Phillips TW, Cuperus G. Stored Product Protection. USA: Kansas State University; 2012.
14. Green PWC, Belmain SR, Ndakidemi PA, Farrel IW, Stevenson PC. Insecticidal activity of Tithonia diversifolia and Vernonia amygdalina. Ind Crops Prod. 2017;110:15-21.

15. Pettit RK, Weber CA, Kean MJ, Hoffmann H, Pettit GR, Tan R, Franks KS, Hotrton ML. Microplate alamar blue assay for Staphylococcus epidermidis biofilm susceptibility testing. Antimicrob Agents Chemother. 2005;49:2612-2617.

16. Sarker SD, Nahar L, Kumarasamy Y. Microtitre plate-based antibacterial assay incorporating resazurin as an indicator of cell growth, and its application in the in vitro antibacterial screening of phytochemicals. Methods. 2007;42:321-324.

17. Mosmann T. Rapid colorimetric assay for cellular growth and survival: application to proliferation and cytotoxicity assays. J Immunol Methods. 1983;65:65-63.

18. Ayaz F, Küçükboyaci N, Duman H, Sener B, Choudhary MI. Cytotoxic, phytotoxic and insecticidal activities of Chrysophthalmum montanum (DC.) Boiss. Turkish J Pharm Sci. 2017;14:290-293.

19. Itokawa H, Oshida $Y$, Ikuta A, Inatomi H, Adachi T. Phenolic plant growth inhibitors from the flowers of Cucurbita pepo. Phytochemistry. 1982;21:1935-1937.

20. Zhang Z, Guo SS, Zhang WJ, Geng ZF, Lian JY, Du SS, Wang CF, Deng $Z W$. Essential oil and polyacetylenes from Artemisia ordosica and their bioactivities against Tribolium castaneum Herbst (Coleoptera: Tenebrionidae). Ind Crops Prod. 2017;100:132-137.

21. Mishra S, Zhang W, Lin Z, Pang S, Huang Y, Bhatt P, Chen S. Carbofuran toxicity and its microbial degradation in contaminated environments. Chemosphere. 2020;259:127419.

22. Rahman MA, Parvin A, Khan MSH, War AR, Lingaraju K, Prasad R, Das $S$, Hussain B, Bhattacharyya A. Efficacy of the green synthesized nickeloxide nanoparticles against pulse beetle, Callosobruchus maculatus (F.) in black gram (Vigna mungo L.). Int J Pest Manag. 2020;67:306-314.

23. Alzahrani SM, Ebert PR. Oxygen and arsenite synergize phosphine toxicity by distinct mechanisms. Toxicol Sci. 2019;167:419-425. 